\title{
Letter
}

\section{Two glaciers collapse in western Tibet}

A $3 \mathrm{~km}$ long glacier collapsed in the morning of 17 July 2016 (Fig. 1). The avalanche killed nine herders living in their summer pasture at Aru Village, Dongru Community, Ritu County, Ali District, Xizang Autonomous Region, the most remote region on the western Tibetan Plateau. The Aru Glacier $\left(34.03^{\circ} \mathrm{N} ; 8^{2} .25^{\circ} \mathrm{E}\right)$, ranges in elevation from 5250 to $6150 \mathrm{~m}$ a.s.l. (CN5Z412C011) and is one of a glacier group that covers $27 \mathrm{~km}^{2}$ (in 2015). The collapsed ice rushed down within 4-5 min (according to eyewitnesses) over the narrow tongue and swept across the gentlysloping alluvial fan, reaching the $105 \mathrm{~km}^{2}$ inland Aruco Lake (Fig. 1).

Figure 2 shows the most recent Sentinel-2 satellite image taken shortly before the collapse (Fig. 2a) and the most recent image taken after the 17 July collapse (Fig. 2b). The detached ice mass (Fig. 2b) is $2.4 \mathrm{~km}$ wide, $5.7 \mathrm{~km}$ long and now covers $9.4 \mathrm{~km}^{2}$. The lower part of the glacier disappeared after the passage of the rapidly descending ice from higher elevation. A survey by differential GPS along the margin of the collapsed ice on 13 August showed an increasing depth from $3 \mathrm{~m}$ at the glacier snout to $13 \mathrm{~m}$ at the distal
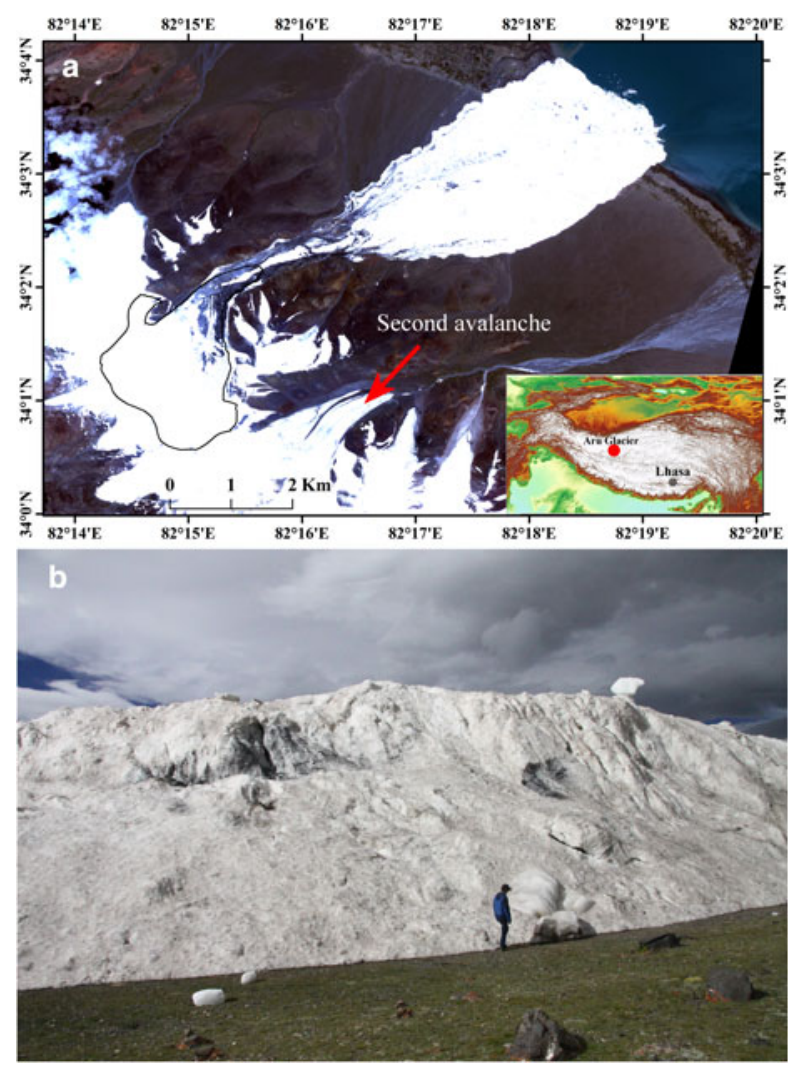

Fig. 1. The Chinese high-resolution satellite Gaofen-2 (band 321) satellite image taken on 25 July 2016. (a) Inset map shows the location of the Aru Glacier and the extent of the runout of the Aru Glacier collapse of 17 July 2016. The avalanche flowed over $6 \mathrm{~km}$ and reached the Aruco Lake. (b) Deposition depths exceeded $10 \mathrm{~m}$. end of the deposit. The average depth of the deposits was estimated to be $7.5 \mathrm{~m}$. This indicates a total volume of fallen ice of at least 70 million $\mathrm{m}^{3}$, or equivalent to an average glacier thickness loss of $\sim 21 \mathrm{~m}$.

The Aru Glacier has been rather stable in the past decades. Landsat imagery confirms that the glacier area has been decreasing from $3.51 \mathrm{~km}^{2}$ in 1970 to $3.49 \mathrm{~km}^{2}$ in 1990 , $3.41 \mathrm{~km}^{2}$ in 2000 and $3.36 \mathrm{~km}^{2}$ in 2010 , which gives a decrease of $0.15 \mathrm{~km}^{2}(4.3 \%)$ over the past 4 decades. Gaofen-1 satellite data indicate that the Aru Glacier area increased slightly from $3.35 \mathrm{~km}^{2}$ on 19 September 2015 to $3.44 \mathrm{~km}^{2}$ on 1 February 2016 and its length increased 75 $\mathrm{m}$ at a rate equivalent to $\sim 200 \mathrm{~m} \mathrm{a}^{-1}$.

Glaciers in this region are not temperate but cold-based and frozen to the bed (Shi and Liu, 2000). Recent research reveals that over recent decades the glaciers in this region have experienced less retreat than those in the Himalayas (Bolch and others, 2012; Yao and others, 2012). Examples include glaciers in the western Kunlun Mountains (Shangguan and others, 2007), the Depuchangdake region just west of the Aru Glacier ( $\mathrm{Li}$ and others, 2016) and to a lesser extent the glacier retreat in Banggong Co with the smallest retreat in the interior area of the Tibetan Plateau (Wei and others, 2014).

A similar glacier event was reported for the Kolka glacier, Northern Ossetia, Russian Caucasus, on 20 September 2002. An enormous rock and ice slide and subsequent mudflow swept through the downstream valley killing over 140 people and causing massive destruction (Huggel and others, 2005). But the Kolka glacier is a hanging glacier experiencing repeated surging (Haeberli and others, 2004). Another very recent glacier surge was on the mountain Tobe Feng, Pamir in western China during the spring of 2015. This glacier advanced $\sim 1.2 \mathrm{~km}$ within 10 months and also caused damage downstream (Lü and others, 2016). It remains to be determined whether the Aru Glacier collapse represents a new type of geo-hazard or a new size of an avalanche glacier similar to those described by Faillettaz and others (2011).

The spontaneous glacier collapse of the Aru Glacier, is, however, not consistent with glacier surging, which exhibits cyclic behavior between quiescent and active phases. Surging glaciers are reported in the Karakoram Mountains (Gardelle and others, 2012), and a few have been reported in the Western Kunlun Mountains (Yasuda and Furuya, 2015), Pamirs (Lü and others, 2016) and in the Tien Shan Mountains (Häusler and others, 2016). However, most surge-type glaciers are characteristically long and wide (Barrand and Murray, 2006), while the Aru Glacier is a relatively small glacier with low annual accumulation and slow velocity. To date, no glacier surging has been reported or observed nearby.

The steep terrain of the surface might predispose the glacier to such an event. With $900 \mathrm{~m}$ of elevation change over a $3.3 \mathrm{~km}$ distance, the glacier has an average slope of $15^{\circ}$. But it is not the only glacier at that elevation with a steep slope in this region. Satellite images show bare bedrock over most of the detached area, indicating rapid basal sliding. This is puzzling as such continental glaciers 


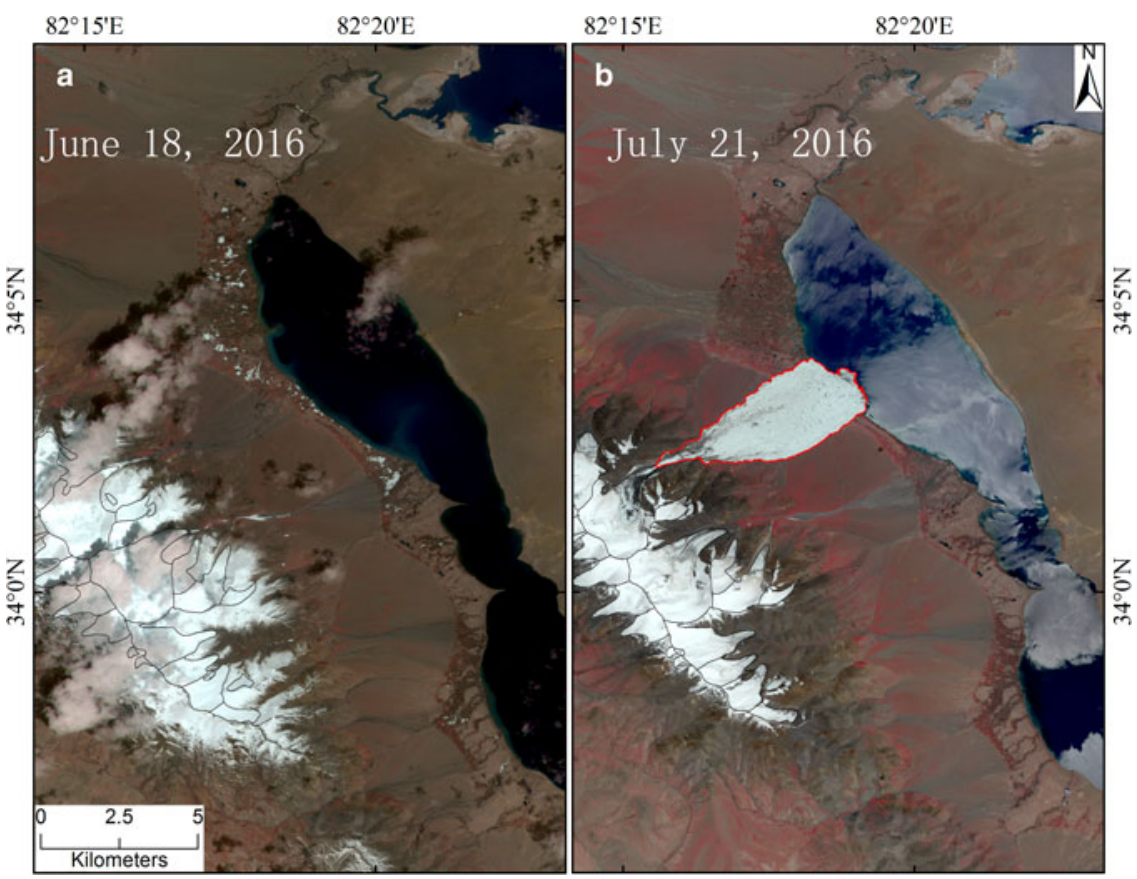

Fig. 2. Images before and after the Aru Glacier collapse on 17 July 2016. Images are from Sentinel-2 on 18 June 2016 (a) and 21 July 2016 (b) with $10 \mathrm{~m}$ resolution.
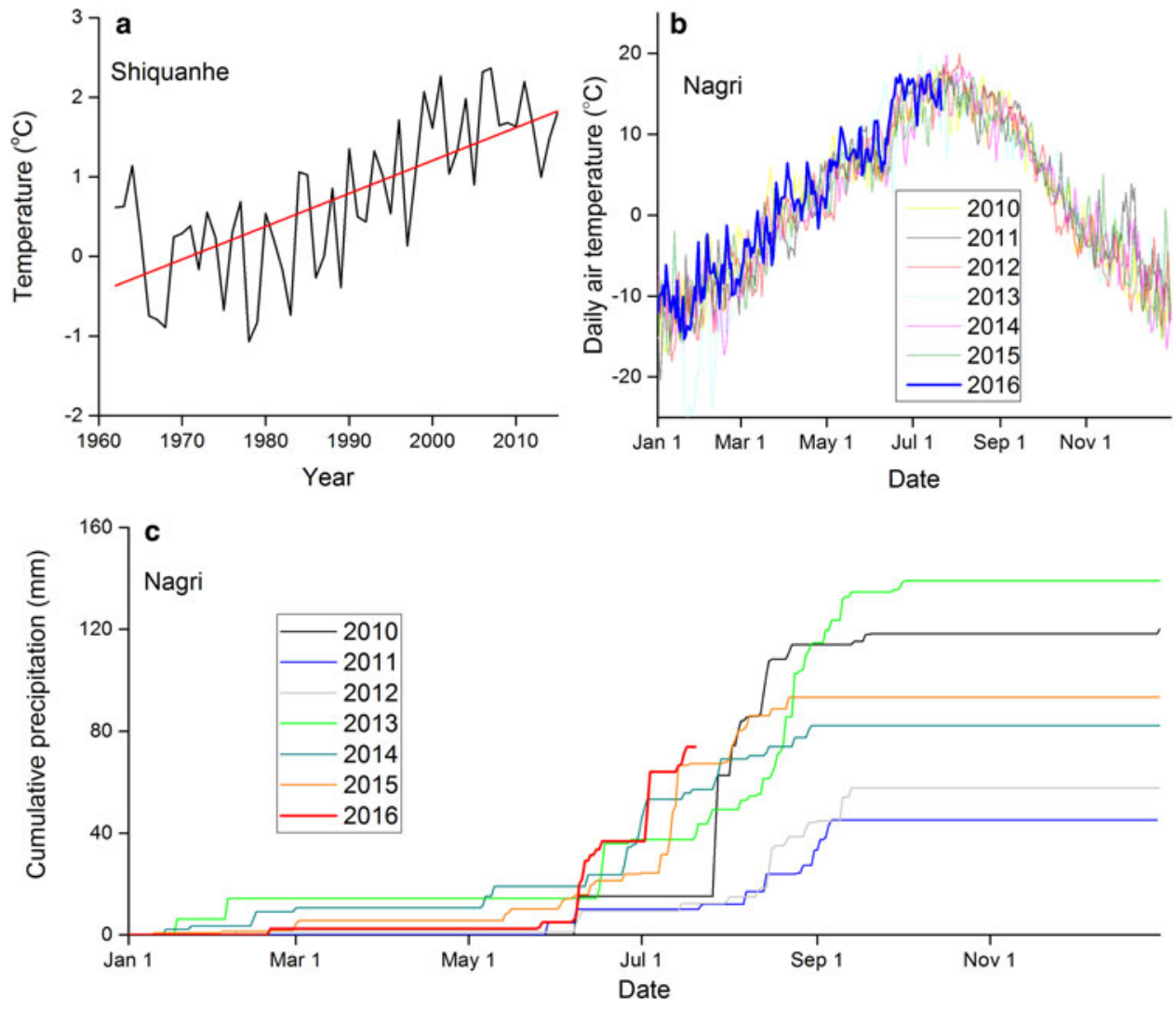

Fig. 3. Warming trend in annually averaged temperature at the Shiquanhe Meteorological Station $\left(32.50^{\circ} \mathrm{N}, 80.10^{\circ} \mathrm{E}, 4260 \mathrm{~m}\right.$ a.s.l.) from 1961 to 2015 (a). Daily air temperature variations (b) and daily cumulative precipitation amount in 2016 (to 20 July) compared with those for each year from 2010 to 2015 (c) as measured at Nagri Meteorological Station (33.39 $\mathrm{N}, 79.70^{\circ} \mathrm{E}, 4260 \mathrm{~m}$ a.s.l.).

are usually assumed to be frozen to the bedrock (Shi and Liu, 2000). Thus, the evidence of glacier sliding might suggest that these glaciers are now in transition from cold base to polythermal due to warming conditions in the region, which thus may threaten the stability of this type of glacier.
Such glaciers are widely distributed over the interior of the Tibetan Plateau.

Recent research reveals that most glaciers on the southeastern Tibetan Plateau are retreating at an accelerating rate while those on the western Tibetan Plateau are either 
stable or advancing (Bolch and others, 2012; Yao and others, 2012). This makes the recent collapse of the Aru Glacier in western Tibet even more extraordinary. It is probable that the recent and rapid warming in this region ( $\mathrm{Li}$ and others, 2010) increased the internal temperature of the ice, which, coupled with increased precipitation, created very unstable conditions. If true, then other glaciers in the region may be experiencing similar conditions, therefore making this region extremely dangerous.

The recent climate warming has been shown to facilitate glacier surging in the Karakoram Mountains (Quincey and others, 2011). But it is unclear whether a local climate change triggered the Aru Glacier collapse as there are no direct weather observations near the glacier. However, it is clear that this region has warmed. Air temperature at Shiquanhe $\left(32.50^{\circ} \mathrm{N}, 80.10^{\circ} \mathrm{E}, 4260 \mathrm{~m}\right.$ a.s.l.), $290 \mathrm{~km}$ southwest of the Aru Glacier, the nearest state-run meteorological station (Fig. 3a), has increased by $\sim 1.5^{\circ} \mathrm{C}$ over the past five decades. Meteorological data (2010-16) from Nagri Meteorological Station $\left(33.39^{\circ} \mathrm{N}, 79.70^{\circ} \mathrm{E}, 4260 \mathrm{~m}\right.$ a.s.l.), $240 \mathrm{~km}$ west of the Aru glacier, show no unusual fluctuations in 2016 and daily air temperatures fluctuate within the long-term range (Fig. 3b). The available climate data do not exclude the occurrence of a very local extreme event. However, the total precipitation at Nagri in 2016 prior to the accident is the highest in the 2010-16 record (Fig. 3c), exceeding the average value by $88 \%$. Moreover, $\sim 90 \%$ of the 2016 precipitation fell within the previous $40 \mathrm{~d}$. Although speculative, if the precipitation pattern at Nagri was widespread, then the overabundance of precipitation (snow) in the spring and earlier summer on Aru Glacier may have strongly contributed to the glacier's collapse.

This is the first known occurrence of an unexpected, instantaneous collapse of a cold-based glacier in a nonvolcanic region. It raises concerns that future events are possible and may pose risks for inhabitants of this region. If the climate warming in the region is the primary cause of the Aru Glacier collapse, then it will not be the last one (the neighboring glacier collapsed on 21 September 2016, with a detached ice area of $6.3 \mathrm{~km}^{2}$ and fallen ice volume of $\sim 100$ million $\mathrm{m}^{3}$, comparable with the first one). Therefore, to implement a continuous monitoring program for these types of glaciers and to design an early warning system is critical. A continuous surveying of the rebuilding of this collapsed glacier may shed new light on our understanding of the processes of glacier formation and collapse. Currently, Tandong Yao and Lide Tian are leading a field investigation into this region, which hopefully will better define the mechanisms driving these two recent glacier collapses.

\section{SUPPLEMENTARY MATERIAL}

To view supplementary material for this article, please visit https://doi.org/10.1017/jog.2016.122

\section{ACKNOWLEDGEMENTS}

We thank editor Graham Cogley, Martin Funk and another anonymous reviewer for comments and suggestions which improved the quality of the manuscript. We are grateful to NASA and USGS for providing Landsat data, and ESA (European Space Agency) for Sentinel-2 data. This research was supported by the National Natural Science Foundation of China (Grant No. 41530748, 41671072), the 'Strategic Priority Research Program (B)' of the Chinese Academy of Sciences (Grant No. XDB03030000) and Major Special Project-the China High-Resolution Earth Observation System (30-Y30B13-9003-14/16-01).

${ }^{1}$ Key Laboratory of Tibetan Environmental Changes and Land Surface Processes, Institute of Tibetan Plateau Research, Chinese Academy of Sciences,

Beijing 100101,

China, ${ }^{2}$ CAS Centre for Excellence in Tibetan Plateau Earth Sciences, Beijing of Cryospheric Sciences, Northwest Institute of Eco-Environment and Resources, Chinese Academy of Sciences, Lanzhou 730000, China, ${ }^{4}$ Byrd Polar and Climate Research Center, The Ohio State University, Columbus Ohio, OH 43210, USA,

${ }^{5}$ Department of Environment and Planning, Shangqiu Normal University, Shangqiu 476000, China

\section{E-mail: Lide Tian <ldt@itpcas.ac.cn>}

\section{REFERENCES}

Barrand NE and Murray T (2006) Multivariate controls on the incidence of glacier surging in the Karakoram Himalaya. Arct. Antarct. Alp. Res., 38(4), 489-498 (doi: 10.1657/1523-0430 (2006)38[489:MCOTIO]2.0.CO;2)

Bolch $\mathrm{T}$ and 11 others (2012) The state and fate of Himalayan Glaciers. Science, 336(6079), 310-314 (doi: 10.1126/ science.1215828)

Shangguan D and 8 others (2007) Glacier changes in the west Kunlun Shan from 1970 to 2001 derived from Landsat TM/ ETM+ and Chinese glacier inventory data. Ann. Glaciol., 46(1), 204-208 (doi: 10.3189/172756407782871693)

Faillettaz J, Sornette D and Funk M (2011) Numerical modeling of a gravity driven instability of a cold hanging glacier: reanalysis of the 1895 break-off of Altelsgletscher, Switzerland. J. Glaciol., 57(205), 817-831 (doi: 10.3189/002214311798043852)

Gardelle J, Berthier E and Arnaud Y (2012) Slight mass gain of Karakoram glaciers in the early twenty-first century. Nat. Geosci., 5(5), 322-325 (doi: 10.1038/ngeo1450)

Haeberli W and 7 others (2004) The Kolka-Karmadon rock/ice slide of 20 September 2002: an extraordinary event of historical dimensions in North Ossetia, Russian Caucasus. J. Glaciol., 50 (171), 533-546 (doi: 10.3189/172756504781829710)

Häusler H, Ng F, Kopecny A and Leber D (2016) Remote-sensingbased analysis of the 1996 surge of Northern Inylchek Glacier, central Tien Shan, Kyrgyzstan. Geomorphology, 273, 292-307 (doi: 10.1016/j.geomorph.2016.08.021)

Huggel C and 6 others (2005) The 2002 rock/ice avalanche at Kolka/ Karmadon, Russian Caucasus: assessment of extraordinary avalanche formation and mobility, and application of QuickBird satellite imagery. Nat. Hazards Earth Syst. Sci., 5(2), 173-187 (doi: 10.5194/nhess-5-173-2005)

Li Q and 6 others (2010) Assessment of the uncertainties in temperature change in China during the last century. Chinese Sci. Bull., 55(19), 1974-1982 (doi: 10.1007/s11434-010-3209-1)

Li Z and 6 others (2016) Changes in glacier extent and surface elevations in the Depuchangdake region of northwestern 
Tibet, China. quarter. Res., 85(1), 25-33 (doi: 10.1016/j. yqres.2015.12.005)

Lü M and 7 others (2016) A rapid glacier surge on Mount Tobe Feng, western China, 2015. J. Glaciol., 62(232), 407-409 (doi: 10.1017/jog.2016.42)

Quincey DJ and 5 others (2011) Karakoram glacier surge dynamics. Geophys. Res. Lett., 38(18) (doi: L18504. 10.1029/ 2011GL049004)

Shi Y and Liu S (2000) Estimation on the response of glaciers in China to the global warming in the 21 st century. Chinese Sci. Bull., 45(7), 668-672 (doi: 10.1007/bf02886048)
Wei J and 6 others (2014) Surface-area changes of glaciers in the Tibetan Plateau interior area since the 1970s using recent Landsat images and historical maps. Ann. Glaciol., 55(66), 213-222 (doi: 10.3189/2014AoG66A038)

Yao T and 14 others (2012) Different glacier status with atmospheric circulations in Tibetan Plateau and surroundings. Nature Clim. Change, 2(9), 663-667 (doi: 10.1038/ nclimate1580)

Yasuda T and Furuya M (2015) Dynamics of surge-type glaciers in West Kunlun Shan, Northwestern Tibet. J. Geophys. Res.: Earth Surf., 120(11), 2393-2405 (doi: 10.1002/2015JF003511)

MS received 23 September 2016 and accepted in revised form 20 October 2016; first published online 9 December 2016 